Portland State University

PDXScholar

\title{
Whose Urban Forest? The Political Ecology of Foraging Urban Nontimber Forest Products
}

\author{
Patrick T. Hurley \\ Ursinus College \\ Marla R. Emery \\ USDA-Forest Service, Northern Research Station \\ Rebecca J. McLain \\ Portland State University, mclainrj@pdx.edu \\ Melissa R. Poe \\ Northwest Sustainability Institute \\ Brain Grabbatin \\ University of Kentucky

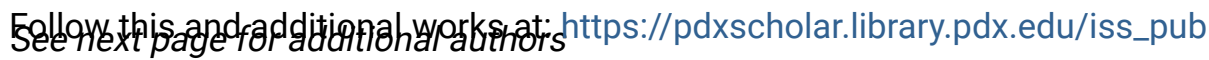 \\ Part of the Geography Commons, Landscape Architecture Commons, and the Sustainability \\ Commons \\ Let us know how access to this document benefits you.
}

\section{Citation Details}

Hurley, Patrick T.; Emery, Marla R.; McLain, Rebecca; Poe, Melissa; Grabbatin, Brian; Goetcheus, Cari L. 2015. Whose urban forest? The political ecology of foraging urban nontimber forest products. In: Isenhour, C.; McDonogh, G.; Checker, M., eds. Sustainability in the global city, myth and practice. New York, NY: Cambridge University Press: 187-212. Chapter 7.

This Book Chapter is brought to you for free and open access. It has been accepted for inclusion in Institute for Sustainable Solutions Publications and Presentations by an authorized administrator of PDXScholar. Please contact us if we can make this document more accessible: pdxscholar@pdx.edu. 


\section{Authors}

Patrick T. Hurley, Marla R. Emery, Rebecca J. McLain, Melissa R. Poe, Brain Grabbatin, and Cari L. Goetcheus 


\title{
WHOSE URBAN FOREST? THE POLITICAL ECOLOGY OF FORAGING URBAN NONTIMBER FOREST PRODUCTS
}

\author{
PATRICK T. HURLEY, MARLA R. EMERY, REBECCA \\ MCLAIN, MELISSA POE, BRIAN GRABBATIN, AND CARI \\ GOETCHEUS
}

\section{INTRODUCTION}

Rather than being regarded as degraded systems of comparatively little ecological value, urban ecosystems should be viewed as young, emergent systems from which we can learn much about ecosystem processes and the role of humans in ecology ... Beyond providing vital ecosystem services, urban ecologies therefore play a vital role in configuring popular understandings of the nonhuman world.

(Francis, Lorimer, and Raco 2012:186)

Cities and suburbs are now home to the majority of the globe's population, and urban expansion in metropolitan areas is expected to continue (Grimm et al. 2008). Despite the significant ways that the urbanization process impacts ecological patterns and processes (Odum 2007), cities increasingly are seen as sites where humans can tackle many contemporary environmental challenges (Ash et al. 2008; Francis et al. 20I2). While cities often lead to new ecological conditions and vegetation characteristics (Francis et al. 20I2), they also include remnants of rural vegetation and land-uses (DelTredici 20I0). Amidst this matrix of ecological change, some see urban sustainability practices as a key to solving the problem of rapid population growth and ensuring efficient resource consumption (Ash et al. 2008). Urban planners, in particular, increasingly stress the importance of developing green infrastructure systems, spaces where ample vegetation and ecosystem elements feature more prominently than concrete, steel, and other impervious surfaces (McLain et al. in press). Yet the governments of cities and their expanding suburbs already have relatively long histories of using parks and other conservation measures to address ongoing concerns 
about environmental degradation and public health (Pincetl 20I0; Black and Chiarappa 2012). An important element of green infrastructure, parks, and other associated protected areas in the cities of the world are their forests, including relatively large contiguous forested areas and the trees lining many streets and parking lots.

Urban forests are socially and ecologically diverse, multifunctional ecosystems (Alberti et al. 2003). Through gathering and other associated practices, these ecosystems provide nontimber forest products (NTFPs) derived from plant and fungal resources for people living in cities and their surrounding suburbs (Community Economies Collective 200I; Robbins, Emery, and Rice 2008; Poe et al. 20I3; McLain et al. in press). In this chapter, we use the term "uNTFPs" to refer to all botanical products, including entire plants, plant parts (e.g., seeds, cones, leaves, flowers, and fruits), plant exudates, and fungi, which are harvested from forested places in cities and their surrounding suburbs. UNTFP species include "wild" plants and fungi (that is, species not altered through horticultural techniques or genetic engineering); "feral" plants (cultivars that spread or persist without intentional human intervention); and the fruits or other desired parts of domesticates where these are incidental to the primary reason for which the specimen was planted. We exclude from consideration animals, fish, shellfish, or insects (see Poe et al. 2013).

Foraging refers to the harvesting, gathering, or collection of these products, which can be derived from native and nonnative, invasive and noninvasive species (see also Poe et al. 20I3). Items such as wild berries, herbaceous weeds, edible mushrooms, blades of perennial grasses, and fallen branches contribute significantly to the lives of many urban residents by supporting both economic and noneconomic needs, such as subsistence, social reproduction and identity formation, and their quality of life (Community Economies Collective 200I; Emery and Peirce 2005; Robbins et al. 2008; Poe et al. 20I3; McLain et al. in press). The people who collect uNTFPs - referred to here as foragers - also are diverse. While research in the United States has revealed that foraging transcends social identity categories of race, class, age, and gender in many places (Robbins et al. 2008; Poe et al. 2013), foraging practices may also be associated with culturally specific foods, crafts, and groups (Emery et al. 2002; McLain et al. in press). In this chapter, we present and discuss case studies that illustrate both types of uNTFP foraging practices - those associated with a particular cultural group and individuals who do not identify with specific cultural ties - as well as gathering activities with differing personal and economic motivations.

Although there is growing recognition of the importance that the urban forest plays for city residents, namely through the contributions of ecosystem 
services to quality of life (Dobbs, Escobedo, and Zipperer 20II), the presence and importance of uNTFPs has been largely overlooked, or worse, devalued by urban planning and conservation science (McLain et al. 20I3). This has prompted planners in U.S. cities and suburbs to largely treat urban forest species as part of a living museum (McLain et al. 20I3). Under the umbrella of green infrastructure, parks, streetscapes, and other spaces are being managed to enhance their ability to improve the quality of air, water, and beauty of cityscapes and certain experiences for urban residents (Benedict and McMahon 2006; Beatley 20II). Some scholars see green infrastructure as creating "biophilic cities" where nature contributes to the health and healing of city residents, thereby leaving room for human-plant interactions such as gathering (Beatley 20II). Still, many urban conservation programs imagine parkscapes solely as backdrops for recreational activities, typically prohibiting direct material interactions between humans, flora, and fauna. Such constructions perpetuate a mythic notion that cities, in particular, no longer contribute to natural resource livelihoods or activities where nature is materially consumed (McLain et al. 20I3). In urbanizing areas, ecosystem service, biodiversity conservation, and to a much lesser extent, working landscape issues such as forestry, have motivated land conservation and protected area creation (Arendt 2004). This has included land set-asides within residential and commercial developments, which are intended to provide space for nonhuman nature and human-centered recreational activities, as well as streetscape greening initiatives intended to reduce stormwater runoff and improve water quality (see Levitan 2013). At the same time, there is renewed interest in the role of food production within some park spaces, including cases of creating orchards within city parks (e.g., Seattle; see McLain et al. 20I2) and planting vegetables or food crops within street easements (see Beatley 20II). Nevertheless, these programs appear to maintain a binary perspective, in which only a limited number of purposefully planted species and deliberately maintained spaces are recognized for their natural resource production value, while many more species and areas are not.

In the limited cases where uNTFP harvesting has been recognized by conservation science research (Wehi and Wehi 2009; Peterson et al. 2012), scholars have come to different conclusions about the sustainability of the practice within urban environments. In South Africa, researchers studying NTFPs gathered in the Cape Town region raise concerns that many species, particularly those for the cut-flower trade, could be harvested at unsustainable levels (Peterson et al. 20I2). Meanwhile, researchers in New Zealand found that urban harvesting of species important to indigenous peoples, particularly those used for medicinal purposes, offset potential harvests on conservation lands 
(Wehi and Wehi 2009). Researchers in Japan have documented the positive role that regularly harvesting fuelwood and edible roots plays in creating habitat for endangered wildlife (Kobori and Primack 2003). These studies focus on the ways that harvesting affects plant physiology and the persistence of particular species. But what does the opportunity to harvest these products tell us about sustainability practices in the city, by which we mean the ability of urban plants to meet the needs of particular "communities of practice" (see Poe et al. 2013) associated with gathering? And to what extent might there be room for different types of uNTFP gathering in the sustainable city?

Using the case of wild-edible foraging in the Philadelphia Metropolitan area and raw-material harvesting for sweetgrass basketry in greater Mt. Pleasant, South Carolina, we point to the presence of actually existing gatherable landscapes and illustrative practices that characterize human interactions within these diverse forested urban spaces. More specifically, we locate the production of these spaces within the typical processes of conservation and development in the United States, the relationship of gathering to the management practices in the resulting divergent spaces, and the ways governance regimes affect access to species valued by gatherers in our study areas (see Lachmund 20I3). Our cases raise questions about the extent to which uNTFP harvesting is seen as a legitimate activity within the contemporary sustainability practices in cities and their suburbs in the United States. Our consideration of sustainability practices is focused on conserved lands and protected areas, including parks of diverse types, as well as characteristic urbanized lands produced by residential and commercial development.

Our case studies of gathering suggest that ideas about what constitutes the suite of appropriate human-environment interactions in the sustainable city are contested and accommodated in diverse ways. Our cases, drawn from ongoing collaborative research, were chosen to illustrate the emerging awareness among researchers that gathering is a practice that can transcend multiple categories of identity, while still recognizing that the harvesting of particular uNTFPs may still be closely associated with the social reproduction and identity formation of particular cultural groups (Robbins et al. 2008; McLain et al. 20I3). Further, these cases reveal the everyday landscapes and places that support these harvesting practices and begin to provide some sense of the extent to which gathering is a permitted or welcomed activity. In this sense, the cases offer further potential for exploring the basis upon which particular gathering activities are or are not viewed as legitimate. At the same time, given the snowball sampling techniques used in these studies, we are cognizant that our research may provide only a partial view of the full diversity of harvesting in cities and their suburbs in the United States. 


\section{TOWARD A POLITICAL ECOLOGY OF FOREST HARVESTS IN URBAN(IZING) AREAS}

\section{Conserving Urban Forests through Green Infrastructure Systems}

Bringing nature back into the city has become a key goal of urban sustainability initiatives in U.S. cities (Beatley 2OII), ranging from the introduction of ecological restoration efforts in long-established urban parks to a new focus on networks of parks, small patches of greenspace (e.g., street planters), and corridors that connect both (Benedict and McMahon 2006; Gobster 2007). This approach, often referred to as "greening" or "green infrastructure," builds upon existing theories and concepts from conservation science that emphasize setting aside land that might otherwise be developed and adherence to landscaping design principles that make urbanized areas function in more ecologically friendly ways. While many parks include remnant natural areas, particularly forest and woodland spaces, from preurban days, newer parks and greenspace areas may be comprised of heavily modified landscapes (Jorgensen and Keenan 20II). From a management perspective, a focus on biodiversity protection and ecosystem service provision in these diverse spaces can privilege species native to the area or management regimes that emphasize water filtration, air pollutant sequestration, and temperature mitigation, among others. At the same time, many management strategies often focus on creating aesthetic and functional environments that urban residents are expected to interact with passively (Gobster 2007; McLain et al. in press).

There is growing appreciation for derelict spaces and informal, unprotected urban wildscapes (Jorgensen and Keenan 20I2) as well as the spontaneous vegetation that can characterize these and other spaces in the city (DelTredici 20IO; Lachmund 20I3) for wildlife habitat provision, contributions to ecosystem services, and human well-being. This emerging perspective challenges conventional views that nature in the city is only found in protected or highly managed park spaces. It also challenges views of ecological management that favor the use of native species only. Specifically, it recognizes the ways that invasive and nonnative species may provide the ecological and social benefits that humans derive from urban nature (DelTredici 20IO; Jorgensen and Keenan 20I2; Lachmund 2013).

Meanwhile, in peri-urban and urbanizing areas in the United States, land conservation approaches have long focused on reducing the density of development through zoning (Rome 200I), in some areas increasing density in conjunction with design approaches such as clustering and concurrent land protection measures (Arendt 2004; Hostetler, Allen, and Meurk 20II), and/or 
acquiring land for ownership by public and private, not-for-profit entities (Fairfax et al. 2004; Duncan and Duncan 2004). While the first two approaches have resulted in diverse management goals and strategies by developers and homeowner associations, the latter has translated into the management of lands by public agencies and land trusts with diverse and often competing missions (Fairfax et al. 2004). Land protected through these techniques is often open to the public, but it is still governed by rules largely derived from conservation science (Hurley and Halfacre 20II)

\section{Political Forest Ecologies: Gaining Access to Forest Products and Services}

Drawing on "rural" political ecology, we note that there is a long tradition of conservation measures being used to control the livelihood and subsistence practices of "local" peoples, most often in the developing world (Brockington, Duffy, and Igoe 2008; Robbins 20I2). From this perspective, states and their conservation agencies often pursue policies that are more about managing people and less about sustainably managing natural resources (Robbins 20I2). In the process, local peoples are dispossessed of land and lose access to natural resources used for social reproduction (Neumann 1998), while forests often become sites of contestation where the rights of particular resource extraction practices, ranging from tree-felling to petty forms of extraction, are asserted and contested. The former may be condoned or actively encouraged and the latter criminalized. Resulting struggles between long-time users and professional managers draw on central tenets - sometimes unquestioned and problematic assumptions - of science to determine harvest types and levels (Peluso I992; Sivaramakrishna 2000). These struggles can play out between ethnic or racial minorities whose livelihood uses are subsequently delegitimized by "outsider" managers and management schemes (Kosek 2006). This perspective on forest politics, we argue, can be more or less directly applied to the examination of urban forests and their management for sustainability in U.S. cities and suburbs, raising questions about what types of resource uses are recognized as belonging and what types are not.

Questioning the legitimacy of particular forest practices in the spaces of conservation is all the more important when one recognizes the existence and persistence of subsistence activities within the rural (Emery and Pierce 2005) and urbanizing spaces of advanced capitalism (Wehi and Wehi 2009; Hurley and Halfacre 20II). In an effort to find food, medicinal, ritual, and craft-related resources (or assets; see Brown I995), rural-resource users turn to specific natural landscapes and the resources these produce as critical strategies in maintaining their livelihoods and cultural identities (Brown I995; Emery and Pierce 2005). 
More recently, there is growing recognition that NTFP harvesting also plays an important role in constructing and maintaining cultural, spiritual, and material well-being in urban locations in postcolonial and postindustrial contexts (Robbins et al. 2008; Poe et al. 2013; McLain et al. 2013).

Political ecological research on private land development and associated conservation practices in the United States has highlighted the ways that the use of tax incentives to purchase land outright or easements, combined with zoning practices, in peri-urban areas can lead to "landscapes of privilege," in which unwanted peoples and practices are pushed out (Duncan and Duncan 2004). At the same time, new housing in urbanizing areas can also have deleterious effects, leading directly to changes in land ownership that reshape environmental management (Walker et al. 2003; Gosnell and Abrams 201 I), limiting the access of long-time rural communities to natural resources for their economic survival (Brown I995; Brogden and Greenberg 2003), and creating conflict when the ideas of residents differ about how best to use natural resources and protect landscapes in urbanizing areas (Brogden and Greenberg 2003; Hurley and Walker 2004). In particular, these changes can silence traditional resource constituencies - including those with intimate knowledge of the ecologies that influence resources - through powerful new discursive alliances (Robbins 2006).

Like their rural counterparts, urban political ecologists question whether city residents have equal access to the urban forests, including large park areas and forested spaces. Their insights reveal the forces that shape the material, social, and discursive dimensions of urban nature, pointing to the ways patterns of development and the distribution of urban nature (Heynen 2003) potentially affect gatherers, what spaces become available to them (see Byrne and Wolch 2009), and how gatherers may need to navigate power relationships with formal land managers and owners (see Brownlow 2005). This provides a broader framework for understanding how the production of green space through changing material and institutional practices impacts gatherers. For example, urban policies and economics can have unexpected consequences for access namely through the creation of ecologies of fear - to parks spaces and species (Brownlow 2005). In the process, safe places where community members could meet in public are abandoned, becoming weedy spaces, overrun by overgrown vegetation and sites of violence.

Thus, for political ecologists in general, questions about urban sustainability practices come down to the ways in which city residents do or do not benefit equally from green infrastructure and the diverse conservation initiatives and landscaping practices that define the creation of green networks. These are tied to questions about social and environmental sustainability, which are inherently political and which cannot be solved by science alone (Heynen, Kaika, and 
Swyngadouw 2006). According to political ecologists, further ecological changes, and the urban sustainability practices that seek to address these, must be placed within the context of historical, social, cultural, political, and economic changes (Heynen et al. 2006). Access to benefits, from this political ecological perspective on gathering, would include equal access for both powerful and marginalized communities to the ecosystem services and improved quality of life provided by parks and other specific spaces that make up a green infrastructure network (Poe et al. 20I3). But they also would appear to include, at the very least, participation in discussions about (if not outright) access to some natural resources from these spaces (see Halfacre, Hurley, and Grabbatin 20IO). These harvests would allow urban residents to literally consume urban nature, whether for subsistence needs or social-cultural reproduction (see Poe et al. 20I3). As our case studies of existing gatherable landscapes demonstrate, this access can be problematic within logics that govern current sustainability management practices, but it can also suggest interesting paradoxes about how we view the possibilities of relatively conventional development. These insights suggest the need for acknowledgment of and greater consideration of gatherable landscapes and gathering practices, including the participation of gatherers, within urban sustainability policy and design processes.

\section{CASE STUDY CONTEXTS AND METHODS}

\section{Philadelphia: Urban Decay and Suburban Expansion}

Although a portion of the City of Philadelphia occupies the Atlantic coastal plain, much of the Pennsylvania portion of the Metro area is characterized by the ridges and deeply dissected stream valleys of the Piedmont Plateau. For this study, we define the Philadelphia, Pennsylvania Metropolitan area (hereafter Metro area) as comprised of Bucks, Chester, Delaware, Montgomery, and Philadelphia counties. Early settlers, including Pennsylvania Germans, made use of the region's abundant forests and their species, both for household needs and early industry, as well as the fertility of subsequently cleared fields. By the end of the mid- to late-nineteenth century, forests in the region largely had disappeared. Since then, however, the area's forests have returned, repeating a familiar story of forest recovery outside key urban centers in the region. While research suggests that rural, nonagricultural practices - timbering, hunting, and fishing among them - continue in the area (e.g., PA Game Commission 2012; PA Game Commission 2009; USDA 2007) despite increasing housing density and forest fragmentation (USDA 2007), there has been less attention paid to NTFP species or harvesting practices and usage, except for specific high-value 
species (e.g., American ginseng; see Burkhardt and Jacobson 2004, 2006). Previous but limited research in the City of Philadelphia has demonstrated the presence of gathering by some residents for food and the importance of harvested species to the individuals' daily lives (Jahnige 2002; Gabriel 2006).

In terms of population, the Metro area is illustrative of the urban and suburban dynamics of decline and expansion in many older cities in the United States (Black and Chiarappa 20I2). Through the early part of the twentieth century, Philadelphia experienced dramatic increases in population, tied both to natural increases and in-migration by diverse groups, many of whom were known to have traditions of mushroom harvesting and other wild edible collecting, including Italians, Eastern Europeans, and many African Americans from the rural South (Amsterdam 2007). In the latter part of the twentieth century, however, fueled by economic restructuring and urban out-migration of principally white residents, the City of Philadelphia experienced dramatic depopulation and social-economic change, while surrounding counties experienced dramatic growth (Mason 20I2). Areas close to the city that had previously been used by wealthy residents as idyllic escapes from the city or as sites of hunting by local residents had rapidly suburbanized. The result was the emergence of stark racial and economic divides between city and suburbs - a divide that has somewhat lessened in recent decades - and a potential divide between rural residents and suburban ideas about appropriate forms of natural resource use.

Although urban sustainability is a relatively new concept, diverse concerns about environmental conservation and associated public health issues have long guided urban policy and practice in the Philadelphia Metropolitan area. The City of Philadelphia is home to one of the largest park systems in the United States; the Fairmount Park system was established in 1855 and now comprises 9,200 acres. As early as the 1960s, activists in the counties surrounding Philadelphia were raising the alarm about disappearing fields and forests (Rybczynski 2007). Over the next few decades, multiple public and private efforts were undertaken to build a robust network of conserved lands reaching from the new suburbs out to the Metropolitan's rural hinterlands. In the I960s and I970s, the state acquired lands to create new parks and develop reservoirs for flood control and recreation purposes (PA DCNR 20I2), but which also added to an existing system of lands managed for game conservation.

As the twenty-first century arrived, the western and more rural portions of Chester, Montgomery, and Bucks counties continued to experience proposals for new suburban and exurban style subdivisions (Mason 20I2). For example, the arrival of a new four-lane highway in western Montgomery County, U.S. 422, had ushered in dramatic suburbanization in previously agricultural and forested parts of the county. Urban development was again consuming the 
rural, pastoral countryside, leading to renewed and expanded efforts at park creation and new conservation areas outside the city. The Pennsylvania Department of Conservation and Natural Resources offered incentives and technical assistance, and bond measures in the counties financed land acquisition by county and local municipal governments. Coordinated efforts by numerous land trusts in the region supported and supplemented these activities. For example, between I953 and 20I2, the Natural Lands Trust built a I,890-acre system of nature preserves across all four counties in the study area (NLT 20I2). Other land trusts have actively acquired lands for their own preserves and purchased conservation easements on private land. Townships have added numerous new parks and natural areas in the past two decades. The emergence of new protected areas has meant potential changes to historic forms of resource use, including activities such as hunting and gathering.

While suburban growth and land conservation boomed, by 2000, Philadelphia was becoming a city of abandoned buildings (Pagano and Bowman 2000; Mason 20I2) and vacant lots (Econsult 20IO). Concerns over safety, public health, and aesthetics were often key topics of discussion. Successive attempts to deal with the situation, including early strategies of neighborhood clearance through urban renewal programs, were met with serious resistance (McGovern 2006). These efforts were replaced by more strategic interventions intended to surgically clean up lots and abandoned buildings throughout the city's neighborhoods. Even groups like the Philadelphia Horticulture Society, building on a history of supporting community gardens, joined in a campaign of greening lots. And some nonprofits' neighborhood guerilla greening activities have turned into full-blown urban farming endeavors (Hurley and Canty in press). More recently, formal planning activities by nonprofits have led to a new plan for the addition of 500 acres of parks through use of vacant lots and abandoned land already owned by the city (Penn Praxis 20II). Like previous initiatives, cleaning up blight and improving quality of life appear to be major drivers of these activities, but these activities are also key features of the city's commitment to urban sustainability and are contributing to an expansion of the existing urban green infrastructure. Still, with the exception of state game lands and community gardens, mostly in dense urban areas, a management philosophy recognizing the harvest of diverse NTFPs is largely absent from this extensive park system.

\section{Rapid Urban Expansion in Greater Mt. Pleasant, South Carolina}

The Charleston Metro area is part of the South Carolina Lowcountry, an area characterized by numerous barrier islands, broad low-lying peninsulas, and tidal 
rivers, but it is perhaps best known for the impact of antebellum rice plantations on its biophysical and social landscape. As part of the rice economy, enslaved Africans made baskets to process and store the harvest. Even after commercial rice cultivation was abandoned, African American baskets remained a common household item. By I9I2, the basket-making tradition developed a dual purpose: cultural preservation and economic earner. Basket-makers from rural settlements along U.S. Highway I7 - north of Mt. Pleasant - promoted the historical, cultural, and aesthetic value of the craft to area tourists and residents (Coakley 2006; Rosengarten I986). Today, basket sales remain an important reminder of the area's heritage and are a part of household economies essential to many African American identities in the area (Grabbatin, Hurley, and Halfacre 20II).

The Greater Mt. Pleasant area, a subset of the Charleston Metro area, is illustrative of many areas in the United States where rapid urbanization is associated with the draw of natural amenities. Indeed, growth in the area is tied to the in-migration of people from parts of the Northeast and the Midwest (see Hurley et al. 2008). In the process, Mt. Pleasant has become one of the South Carolina's fastest growing cities (US Census 2009). Early suburbanization transformed farmland on higher ground, particularly along U.S. Highway I7. But after Hurricane Hugo hit in I989, growth accelerated, and subdivisions increasingly encroached on historic rural African American settlements (Hurley et al. 20I2). Today, newer subdivisions are often in lower-lying areas and adjacent to tidal waterways. They include numerous upscale planned communities, with gated entries and well-landscaped ornamental plantings, extensive walls surrounding communities, common areas characterized by "islands" of forest or forested wetlands, and panoramic views of tidal wetlands. Golf courses, waterfront parcels with private docks, and recreational trails are also common.

Urbanization has been accompanied by dramatic socioeconomic and racial demographic changes. Over a century ago, 70 percent of the population in South Carolina's coastal counties was African American, while whites made up just 30 percent (US Census 2007). By I990, the percentage of African Americans in Charleston County and Mt. Pleasant had declined to 34.9 and I5.7 percent respectively (US Census 2007). Today, African Americans comprise 29.8 percent of Charleston County residents and just 5.5 percent of the population in Mt. Pleasant (US Census 20I3). Rapid development, given the abundance of water- and forest-related natural amenities, has been fueled principally by white in-migrants, whose higher incomes, retirement savings, and home equity have increased land values substantially and led to gentrification pressures in historic African American settlements (Hurley et al. 2008). These gentrification pressures have had important implications for entire communities and the basket-makers they support (see Hurley et al. 2008; Grabbatin et al. 20II). 
Conservation is a longstanding tradition in the Lowcountry (Earley 2004; Lee 2009; Halfacre 2012), but in recent decades, a number of organizations have actively supplemented the work of public agencies (Lee 2009; Halfacre 20I2). Since the first half of the twentieth century, federal agencies have been active in regional conservation. Founded in 1936, the Frances Marion National Forest (FMNF) borders a number of rural African American settlements in Charleston County. Just east of FMNF and located on the coast is Cape Romain National Wildlife Refuge, whose early history as a hunting preserve owned by a New York banker illustrates both early conservation efforts in the region and the ways outsiders have shaped local land use. More recently, private land trusts, such as the Lowcountry Open Land Trust, have been actively engaged in purchasing conservation easements, including lands associated with planned-unit developments (Hurley and Halfacre 20II), in rural landscapes being transformed by development. Likewise, many developers have engaged in creating sophisticated communities, whose open space areas are designed to meet requirements for wetlands protection, reinforce the area's sense of place through native species plantings, and/or that specifically seek to conserve natural attributes (Hurley and Halfacre 20II). Many but not all of these communities feature gated entrances and other design elements intended to dissuade entrance by noncommunity members. Given the socio-demographic shifts afoot, the location of these residential communities, and the tendency for names to invoke "plantation" heritages, these emerging urban landscapes carry significant overtones of racial and class exclusion. Taken together, these dynamics suggest a transition away from a landscape recognized for its natural resource or extractive values, particularly for marginalized cultural groups, and toward one valued for its natural amenities, aesthetic values, and recreational opportunities.

\section{Methods}

To examine the practices associated with the existing gatherable landscapes of our cities and suburbs, our project uses a mixture of standard qualitative methods and GIS data to show how complex social and ecological processes support NTFP harvesting by gatherers in urban spaces (Knigge and Cope 2006; Hurley et al. 2008). In Pennsylvania, our research documents the diversity of NTFP gathering in the city and its suburbs; generally which types of plant and fungi species are harvested and why (drawing on a review of regional field guides and interviews with gatherers); how these species are used; the places from which these species are collected; and the types of locations where gatherers gain access to selected species. First, we draw on ongoing in-depth interviewing, which relies on snowball sampling techniques with gatherers since Fall 2009. Second, 
we also base observations on interviews with managers: at state parks in all four counties; land trust preserves in Chester, Delaware, and Montgomery counties; county parks in Montgomery and Chester counties; the City of Philadelphia parks department; and the region's two national parks.

In South Carolina, our research documents the ways that harvesting associated with the craft is transformed by urbanization. First, ongoing research maps changes to known distributions of sweetgrass and potential collecting sites (see Hurley et al. 2008). This information is supplemented with in-depth interviews at multiple stages, in which we employed convenience and snowball sampling techniques to recruit interview participants (see Hurley et al. 2008; Grabbatin et al. 20II). Second, we have completed oral histories, community tours, community presentations, and field-mapping exercises with residents particularly elderly residents and basket-makers - from ten African American settlements to document contemporary harvesting locations and strategies (see Hurley et al. 2013 for a discussion of methods and analysis).

\section{FORAGING SUSTAINAB(I)L(IT)Y IN THE CITY AND SUBURBS?}

\section{Unrecognized Resources, Illegitimate Harvests?}

Individuals from very different backgrounds living in the City of Philadelphia and its suburbs harvest a diverse array of species. Of the gatherers in the region we've interviewed $(N=35)$, only a few are relatively new to gathering, while many had previous family or childhood experiences. Ages vary, ranging from individuals in their early twenties to others in their mid-sixties. All of our informants, except one, identified as white, and only a few sought to highlight specific European cultural roots. Interviewees report collecting a total of I64 species (I60 plants, four fungi) and their parts, as targeted for collection, with individual harvest targets ranging from two to three species to one individual who harvested I22 species. The total of I64 species represents less than onehalf of the gatherable species $(N=487)$, by which we mean species known to provide parts that have utilitarian value found in the region. Although edible parts of species, including a variety of berries, fruits, and other parts, were among the most commonly harvested, our informants also harvested several species for their medicinal properties (e.g., dandelion root and red clover) as well as some for use in craft-related activities (e.g., eastern white pine needles and black walnuts). Edible species included berries such as wineberry, serviceberry, and raspberry; other fruits such as paw paw, persimmon, beach plum, and more typical orchard fruits found in the region; greens such as dandelion, burdock, and garlic mustard; and nuts such as walnut and diverse hickory species. Others, 
such as gingko nuts, are less widely harvested. Only one species of conservation concern in the region, wild leeks (also known as ramps), was identified as being regularly harvested. Our respondents did not list other target species, such as goldenseal and ginseng. Not surprisingly, given the heavy emphasis on wild fruits, nuts, berries, and edible plant parts above, people told us they foraged as part of recreational food pursuits and their personal concerns about creating local food systems. Only a few individuals indicated that gathering was part of either a direct strategy to earn some extra money, or generally part of a strategy of substituting for store-bought items through strategic collection. That said, many gatherers engaged in the collection of edible and nonedible species for use in treating health issues, ranging from teas for liver health to use in bath treatments for healthy skin. We note, however, that many of our informants were recruited through networks specifically associated with food gathering or foraging.

Indeed, wild edible gathering has become one way that individuals in the area are seeking to form a community of practice (Poe et al. 20I3). For example, since September 20I0, the online "meetup" community "Wild Foodies of Philadelphia" has existed and grown. As of August 20I2, the site featured 623 members. The "Wild Foodies" organize weekly or twice-weekly outings throughout the spring, summer, and fall as well as semi-monthly outings during the winter. Proclaiming, "there's food beneath your feet," the group's page says they're "about": "wild edible plant recognition, edible wild mushrooms, edible schoolyards in Philadelphia, wild foods ... edible landscaping, edible weeds and insects, and wild edibles" (Wild Foodies of Philadelphia 20I2). Out of fifty-nine organized or advertised events - some organized or sponsored by or with other meetup groups - a high number have taken place in city parks, a few at local arboretums or botanical gardens, several on sections of the regional bike trail system, and a couple at private nature preserves in the suburbs. While many of these outings are led by one of the group's founders, the group has advertised at least three events where renowned New York City gathering expert Steve Brill has been a guest tour leader. Other events have featured "professional foragers" (or gatherers) from the Philadelphia area. The group has also begun to recruit and train individuals to serve as guides on outings.

"Wild Foodies" events, particularly those that take place in area parks and on regional trail systems, represent an implicit challenge to the formal system governing plant management in many parks and protected areas in the region (see Figure 7.I). Although the group regularly informs attendees that harvests are for the most part illegal, the goals of the group suggest an effort to push the boundaries of acceptable foraging practices. It is also interesting to note that the group often focuses on nonnative or invasive species, implicitly raising questions about the ways gathering may help to remove troublesome species. By contrast, 


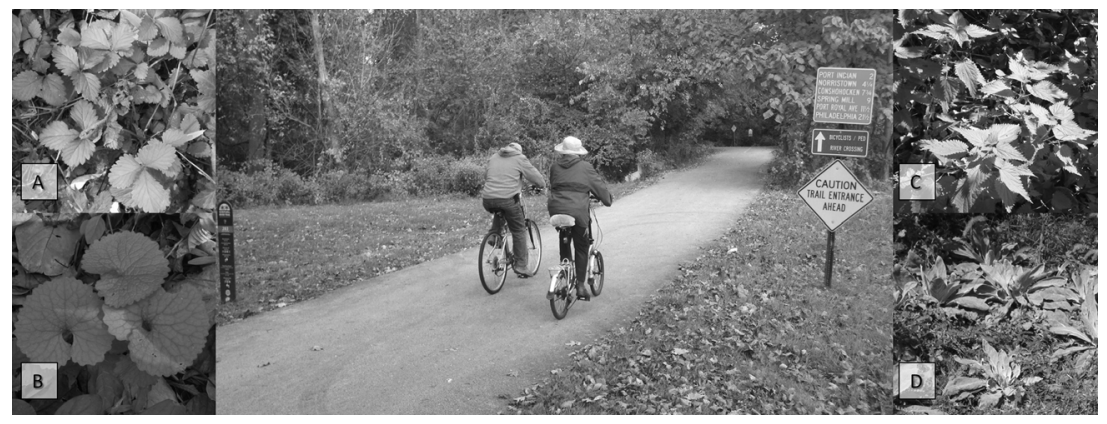

Figure 7.I: Wild foodies meet-up event, Montgomery County, PA. (Photo: P. Hurley.)

wider gathering activities by other individuals in the region clearly represent an explicit - if not purposeful - challenge to park rules and management logics. Indeed, interviews suggest that, while Philadelphia area gatherers harvest on institutional grounds ranging from college campuses and arboretums to schoolyards and church grounds, along roadsides in suburban areas, and from nature preserves at the rural-urban fringe, harvesting species are predominantly harvested in local parks of all types.

For the most part, the harvest of wild plants and planted species treated as wild by gatherers, is illegal and officially frowned upon in Philadelphia City parks, the various county parks and trail systems, and on land trust-owned nature preserves. This policy disposition ranges from explicit prohibitions, such as "Defacing or damaging park property ... and/or disturbing or removing wildlife or vegetation is prohibited," in park regulations (see Figure 7.2) to discussions about the need for greater enforcement of plant collection in regional conservation documents. Although enforcement of these restrictions is uneven and irregular according to interviews with managers, some gatherers worry about the illegality of their practices in spaces where it is prohibited. Meanwhile, state parks, state game lands, and the region's two federally-owned parks (outside the city) allow the collection of nuts and berries as well as fungi, but only if plants or other plant parts are not injured. Some managers indicated that they would be comfortable with the collection of invasive species. Harvest volumes in areas where collection is permitted are typically restricted to amounts considered enough for one person's consumption for one day. Thus, one can gather a gallon-sized bucket of blackberries from Hopewell Furnace National Historic Park, but not the leaves of a sassafras shrub. Likewise, one cannot legally gather berries in such abundance, so as to sell at a local farmer's market. No manager reported seeing any violations of these limits, yet at least two informants indicated that they do 


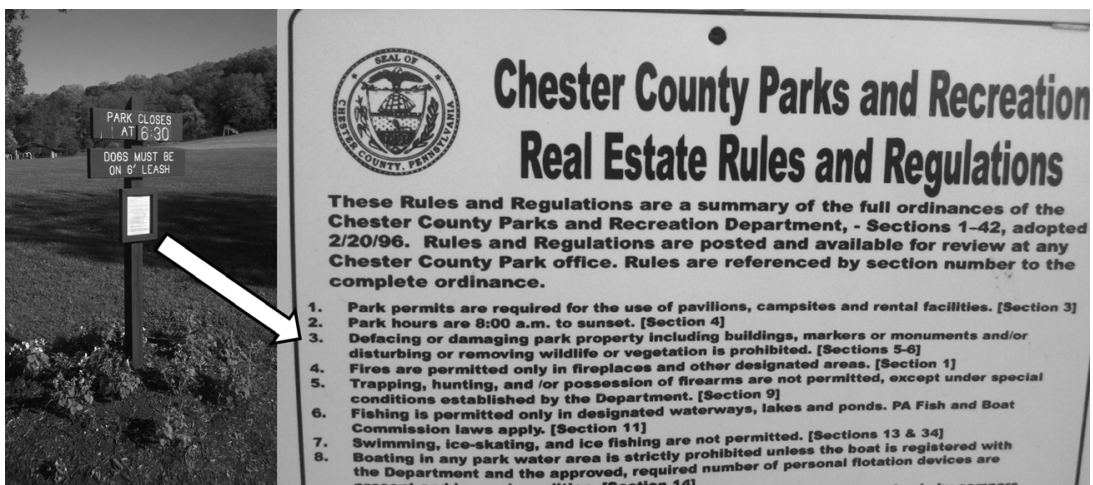

Figure 7.2: Regulations, indirectly addressing gathering, Chester County Park. (Photo: P. Hurley.)

gather some species, including berries, petals, greens, and mushrooms in quantities sufficient for sale at farmer's markets and to local restaurants.

Beyond the activities of "Wild Foodies," interviews with managers who had had direct conversations with gatherers pointed to harvests of gingko nuts by "Asian women" from trees in a city park and along neighborhood streets, the harvest of wild leeks or "ramps" by individuals of Hispanic origin from a suburban nature reserve, mushroom collecting by an Italian immigrant in a nature reserve in a more rural setting, and the illegal harvest of purslane by Italian immigrants from a county "farm park." While food can be gathered from diverse locations in the city, many gatherers do express concern about issues of safety, including both the proper identification of species as well as taking steps to minimize exposure to toxic chemicals and other hazards (e.g., herbicides, pesticides, heavy metals, or microbes associated with dog feces).

The activities of the Wild Foodies and other gatherers challenge a predominant way of seeing urban nature and the place of particular species in it, specifically different notions of which species are useful and which may have a legitimate presence in the urban forest. Observations of Wild Foodies events reveals the organization's focus not only on the edibility or medicinal value of plant species, but also a specific effort to educate city residents about the utility of ubiquitous, invasive and nonnative species. To some extent, this focus is a function of these species' ubiquity, but it also becomes clear that many of those involved are forging what they see as a healthier relationship to urban ecosystems by finding value for species that are either underappreciated or that may become targets for what they view as toxic management practices using herbicides. To this end, common plantain, purslane, and dandelions represent species in the urban forest understory that should be valued, not sprayed out of existence. Even species such 
as garlic mustard and Japanese stiltgrass are recognized for their value in meeting human consumption needs - species that managers see as troublesome invasives with deleterious consequences for local forest ecosystems.

\section{"Urban” Landscaping Opportunities?}

Basket-makers, of all ages, living in historically rural settlements in the Greater Charleston Metro area sew together rows of sweetgrass, longleaf pine needles, and bulrush cuttings with strips made from palmetto fronds. All four plant materials historically occurred in local woodlands and wetlands throughout much of the Lowcountry. Sweetgrass, the signature resource used in basketmaking, occurs naturally along beach dunes and in the interface between wetlands and woodlands (Ohlandt I992), while palmetto has long been found within maritime forests, long-leaf pine in diverse forest types historically maintained by fire, and bulrush in tidal marshes. Sweetgrass typically contributes to the bulk of each basket, and currently is the most difficult material to obtain (Hart, Halfacre, and Burke 2004; Grabbatin et al. 20II). Resource supplies were and continue to be amassed through familial collecting efforts or purchased from harvesters in one or more of the rural settlements outside the Town of Mt. Pleasant (Derby I980; Hart et al. 2004; Grabbatin et al. 20II). Sweetgrass was found in a number of places in the greater Charleston metropolitan area, but commonly in areas surrounding African American settlements (Hurley et al. 2008, 20I2). While long-leaf pine was until recently relatively abundant in the Francis Marion National Forest (Earley 2004) and found sporadically within forested areas of the greater Mt. Pleasant, palmetto is relatively common in wild and semi-wild areas and bulrush is found in abundance along the terrestrial-tidal fringe of the area's peninsulas.

Unlike foraging by many informants in the Philadelphia region, the harvest of sweetgrass, palmetto fronds, longleaf pine needles, and bulrush stems goes back multiple generations. As late as fifty years ago, the system of access that governed basket-making was one in which basket-makers and their family members harvested materials from woodlands, forests, and marshland fringes that were either adjacent to or surrounded their settlements. These largely unmanaged ecosystems provided both the materials for basket-making and numerous other NTFPs, including wild food, medicinal, and other ornamental and craft-related species. These ecologies were treated as de facto resource commons that were seen as key parts of African American communities, but that were embedded within a property regime characterized by privately owned land in a regional economy tied to agricultural and timber production. In some places, this land was owned by nearby white farmers or absentee owners, but not farmed, or by 
members of the community itself. In either case, access to harvest materials was an accepted local practice, either because the owners approved access or because it was not monitored.

With the spread of white, middle-class, and amenity-driven suburbanization in the Town of Mt. Pleasant, a largely rural economy and landscape began to unravel (Hurley et al. 2008, 2012). Beginning in the I970s and accelerating in the I990s following Hurricane Hugo's I989 landfall in the area, residential and commercial development dramatically transformed the landscapes from which materials were harvested. African American settlements that were once surrounded by scrub shrublands, woodlands, and forest were now surrounded by suburban subdivisions and a new, emergent urban forest (Hurley et al. 20I2). This new housing repeatedly appeared in locations identified as areas within historic community boundaries and identified as resource commons from which diverse NTFPs - not just basket-making materials - had been previously collected. Largely unmanaged ecosystems were treated as de facto commons characterized by well-accepted norms of access, and they had become a mosaic of private parcels owned by individual residents and common areas owned by homeowner associations and commercial development corporations. In these spaces, land management objectives centered primarily on suburban aesthetics. In the late I980s and early I990s, many basket-makers and other local observers, including some politicians and resource scientists, had begun to talk about the ecological destruction or disappearance of, in particular, sweetgrass (Proceedings I988; Dufault et al. I993; Rosengarten I994). Early efforts to grow the species on institutional lands as well as encourage basket-makers to grow the species in their yards largely failed, but proliferation of the plant began to occur in new gated communities and residential developments (Dufault 20I2). In response to this process, basket-makers began to develop new harvest strategies, including traveling farther afield. They also sought new ways to further influence development policy and its effect on the emerging (suburban) forest landscape.

Thus, in Mt. Pleasant's transition to a suburban landscape, an interesting social-ecological trend began to emerge. Social networks emerged among basket-makers and individual suburban residents (newcomers to the area), which resulted in basket-makers obtaining materials from privately owned, urbanized areas to meet some of their supply needs (see Figure 7.3). The emergence of an uneasy alliance among planners, elected officials, developers, and extension scientists had resulted in increasing numbers of sweetgrass plants (Dufault 2013) as well as palmetto trees being planted in the common areas of new planned unit developments and commercial shopping centers. Many developers, including among some in other areas of the region, appeared to have recognized the significance of these showy species for reinforcing a particular sense of place 


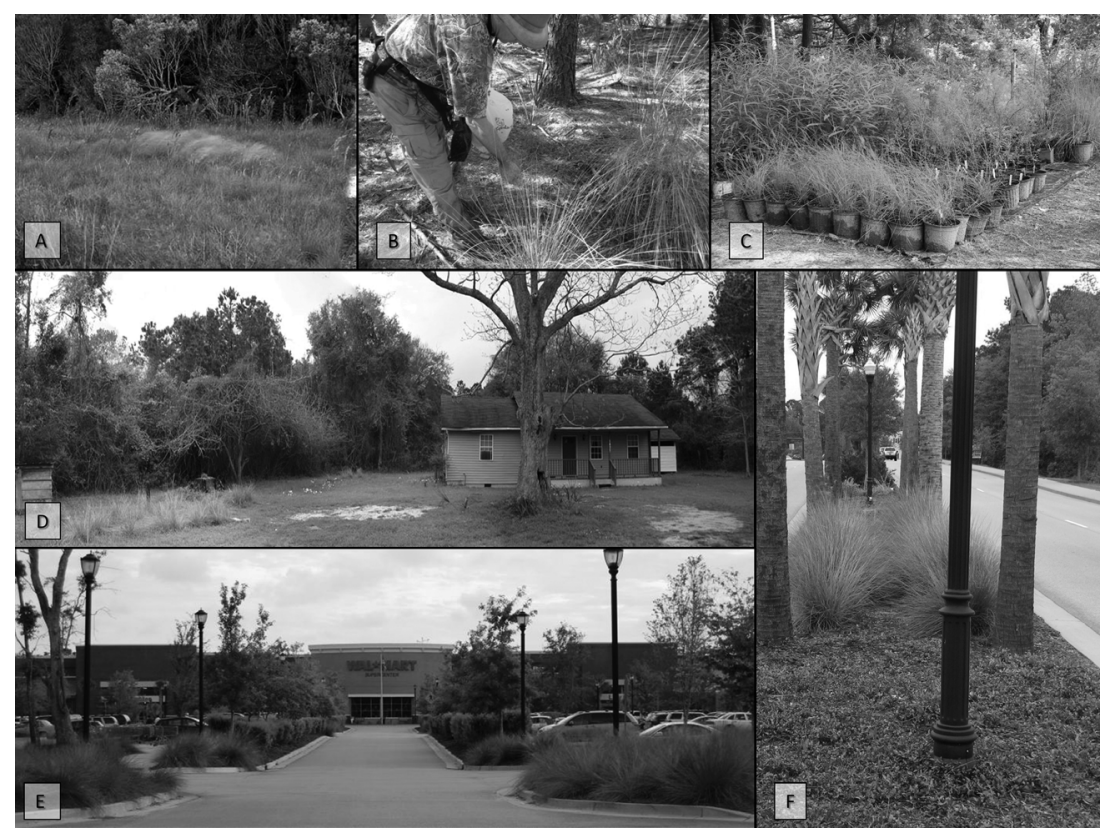

Figure 7.3: Diverse harvest sites. (Photo: B. Grabbatin.)

associated with the Lowcountry. For example, the resort development on Kiawah Island includes abundant sweetgrass plantings in areas not part of any conservation efforts, while Dewees Island is a development based on a conservation principle that has restored sweetgrass. By the end of 2008, Mt. Pleasant's newest shopping center, anchored by Walmart and Kohl's, featured more than Ioo sweetgrass plantings, some palmetto trees, and even longleaf pine trees in scattered places around the parking lot and its main entrance. Three of four basketry NTFPs were in one place - nearly one-stop shopping for harvesters.

As these landscaping trends have solidified, new initiatives by basket-makers and their allies have begun to create a new, more formalized system of access to these plants growing in very nontraditional spaces. Harvests of sweetgrass in fall 2007 and 2008 at Kiawah Island set a precedent for resource collection in the commons of high-end gated communities. Since then, and under the auspices of the Sweetgrass Cultural Arts Festival Association, an organization made up principally of local African American business people, a local African American politician, and several basket-makers and community members, another four locations have "opened their gates" to harvest. The resulting harvests are highly organized and formalized collecting visits in which basket-makers, who have paid a yearly fee of $\$ 25$, are allowed to gather grass. The process is overseen by a 
steward, who is responsible for making sure that the area is left in an acceptable condition. Thus, now even in the parking lot of a Walmart store (see Figure 7.3), sweetgrass is harvested by individuals for use in baskets that are sold in simple wooden stands, some also located in the parking lots of nearby commercial and residential developments.

\section{URBAN FORESTS: SPACES OF PRODUCTION, SPACES OF SUSTAINABILITY}

Urban NTFPs contribute to the household incomes and daily lives of individuals living in the Philadelphia metropolitan area and greater Charleston, South Carolina. In Pennsylvania, individuals harvest a diverse array of species for personal consumption or for gifting to friends and family. Only a few individuals spoke of selling the items they had gathered. Gathering was part of a commitment to a healthier lifestyle and more intimate engagement with nature. In South Carolina, the children and grandchildren of basket-makers carry on a cultural artform that was brought to the United States by enslaved Africans. Many supplement their weekly earnings, including retirement income and social security, with sales of their baskets. Some continue the tradition of eating wild foods when harvesting sweetgrass, although this tends to happen further afield of Mt. Pleasant. However, the social and regulatory terms under which access to resources in both cases continue to constrain household earnings.

Urban gatherers, both long-time gatherers and relative newcomers, interact with urban forests in unexpected ways. Pennsylvania gatherers come from diverse backgrounds, both in terms of socio-demographics and personal history with NTFPs. Still, we are reminded that, given the limited sampling for this study, our current understandings likely overlook similar and additional practices by individuals with other ethnic or racial backgrounds. Nevertheless, these gatherers are creating new relationships with the everyday urban landscapes that characterize U.S. cities. This emerging relationship shifts the valuation of species more commonly thought of as "weeds" from useless to useful. In South Carolina, the landscapes that support basketry have been dramatically transformed by decades of residential development. In the process, basket-makers have successfully adapted their harvest strategies. Thus, the natural resource demands of this African basket-making technique were not only successfully adapted to the local ecologies of a new world, but contemporary basket-makers continue meeting their resource needs through novel ecological systems found in urban landscapes.

The Philadelphia, Pennsylvania, and Charleston, South Carolina, metropolitan areas feature existing gatherable urban landscapes, even if they are not immediately recognized by land managers or the general public. These 
landscapes function as, and have great potential as, sites of sustainable natural resource production. In Philadelphia, as elsewhere (McLain et al. 20I3), people are consuming the city: its recognized and unrecognized food abundance, species, and derivatives that contribute to people's well-being and perceived health, and the materials the urban forest provides for crafts. The persistence of sweetgrass basket-making outside Charleston, South Carolina, in spite of the ecological transformations wrought by forms of urban development that deviate only minimally from conventional approaches, provide further insights into the ways that urban landscapes might be reimagined and designed as sites of natural resource harvest. In short, the future of sweetgrass basket-making may now rest on a rather paradoxical notion: if basket-making is to continue, it may be elements of the urban forest that now produce the key supply of natural resources for this historic livelihood, which has long relied on local ecologies, to persist. Yet we are reminded that these are the very spaces of urban and suburban sprawl, suggesting the need for wider engagement of greenspace planning with livelihood ecologies in the city.

Formal greenspace management systems are only beginning to recognize uNTFPs and gathering as a practice of consequence for urban sustainability and existing management paradigms (see McLain et al. for an outlier). Our cases suggest the need for greater policy and design consideration of gatherable landscapes within urban sustainability practices. While managers may be quick to conclude that gathering threatens the persistence of rare and valuable species, drawing on traditional conservation science insights and concerns, in Pennsylvania the suite of species currently targeted for collection by gatherers do not include species of conservation concern. Likewise, gatherers mostly harvest for personal consumption and in quantities that appear to reflect manager's informal sentiments about the practice. Basket-makers in South Carolina appear to currently harvest in ways and in quantities that are acknowledged as compatible with the persistence of all four species, given present ecological and land management conditions. Urbanization likely would have been a bigger threat to the persistence of some species, if not for changing landscaping practices. Indeed, the proliferation of desired species in urban ornamental landscaping now appears to further livelihood conservation by potentially providing adequate resource supplies. It's worth reiterating here that, quite literally, basket-makers are beginning to win back access to the geographic locations from which they once harvested, albeit now from places governed by radically different management and tenure regimes in residential and commercial spaces characterized by intentional landscaping practices. However, the nature of this access is precarious, given that it depends on negotiation with new landowners and the establishment of systems that ensure harvesting does not degrade expensive landscaping. 
In thinking about policy and design, the full and equal participation of uNTFP gatherers in discussions about wider aspects of urban sustainability is still an open question. In Pennsylvania, there is no indication that gatherers are becoming active in planning or policymaking discussions. That said, the example of the Wild Foodies Meet-up group points to the possibility of engagement with policy-makers, whether initiated by managers or the group itself. In South Carolina, a number of basket-maker organizations continue to work directly and indirectly with policymakers and developers to continue creating an alternative supply network. The success of their efforts remains unclear. Taken together, though, the cases of Philadelphia and South Carolina gathering provide examples of the need for uNTFPs to be seen as components of livelihoods as well as important forms of nature interaction that depend on urban social-ecological systems (see Poe et al. 20I3). These cases of urban gathering also further dispel the myth that urban ecosystems only meet nonconsumptive uses, while simultaneously challenging the inclusiveness of urban sustainability policies that focus only on ecosystem service provision (see McLain et al. 20I3). To adequately locate and accommodate urban gathering in urban sustainability policy, however, will likely require that managers look beyond their preconceived notions about how uNTFPs are incorporated into gatherer's lives, the motivations that drive gathering, where uNTFPs are found and how they are collected, and how - if at all - these activities threaten the sustainability of targeted species.

\section{ACKNOWLEDGMENTS}

We thank the many basket-makers and members of the Greater Mt. Pleasant, SC community as well as urban gatherers in the Philadelphia Metropolitan area who have participated in the respective research studies. Research in South Carolina has been supported by the South Carolina Department of Archives and History, while data collection in Pennsylvania has been supported by the Office of the Academic Dean at Ursinus College. Laura Brody, Martina Dzuna, Vinnie Dombay, Adam Schwemin, Emily Ramsay, and Brendon Satmary provided research assistance with data collection in Pennsylvania.

\section{Works Cited}

Alberti, Marina, John M. Marzluff, Eric Shulenberger, Gordon Bradley, Clare Ryan, and Craig Zumbrunnen 2003 Integrating Humans into Ecology: Opportunities and Challenges for Studying Urban Ecosystems. BioScience 53(I2):II69-79.
Arendt, Randall 2004 Linked Landscapes: Creating Greenways Through Conservation Subdivision Design Strategies in the Northeastern and Central United States. Landscape and Urban Planning 68:24I-69.

Ash, Caroline, Barbara Jasny, Leslie Roberts, Richard Stone, and Andrew Sugden 2008 
Introduction: Reimagining cities. Science 319:739.

Beatley, Timothy 20II Biophilic Cities: Integrating Nature into Urban Design and Planning. Washington, DC: Island Press.

Benedict, Mark A., and Edward T. McMahon 2006 Green Infrastructure: Linking Landscapes and Communities. Washington, DC: Island Press.

Black, Brian C., and Michael J. Chiarappa 2012 Nature's Entrepot: Philadelphia's Urban Sphere and its Environmental Thresholds. Pittsburgh: University of Pittsburgh Press.

Brockington, David, Rosaleen Duffy, and James Igoe 2008 Nature Unbound: Conservation, Capitalism, and the Future of Protected Areas. London: Earthscan.

Brogden, Mette, and James Greenberg 2003 The Fight for the West. Human Organization 62(3):289-90.

Brown, Beverly I995 In Timber Country: Working people's Stories of environmental Conflict and Urban Flight. Philadelphia: Temple University Press.

Brownlow, Alec 2005 An Archaeology of Fear and Environmental Change in Philadelphia. Geoforum 37(2):227-45.

Burkhardt, Eric, and Michael G. Jacobson 2004 Nontimber Forest Products from Pennsylvania, I: American Ginseng. College of Agricultural Sciences: Agricultural Research and Cooperative Extension. University Park: Pennsylvania State University.

Burkhardt, Eric, and Michael G. Jacobson 2006 Nontimber Forest Products from Pennsylvania, 2: Goldenseal. College of Agricultural Sciences: Agricultural Research and Cooperative Extension. University Park: Pennsylvania State University.

Byrne, Jason, and Jennifer Wolch. 2009. Nature, Race, and Parks: Past Research and Future Directions For Geographic Research. Progress in Human Geography 33(6):743-65.

Coakley, Joyce 2006 Sweetgrass Baskets and the Gullah Tradition. Charleston: Arcadia Publishing.
Community Resources, Inc. 2000 The Bounty of the Urban Forest: The Uses and Values of Urban Non-Timber Forest Products. www. urbanforestrysouth.org/resources/library/thebounty-of-the-urban-forest-the-uses-andvalues-of-urban-non-timber-forest-products/ file, accessed December 3I, 2010.

DelTredici, Peter 2010 Spontaneous Urban Vegetation: Reflections of Change in a Globalized World. Nature and Culture 5(3):299-3I5.

Dobbs, Cynnamon, Francisco Escobedo, and Wayne Zipperer 20II A Framework for Developing Urban Forest Ecosystem Service and Goods Indicators. Landscape and Urban Planning 99: 196-206

Dufault, Robert 2012 Stalking the Wild Sweetgrass: Domestication and Horticulture of the Grass Used in African-American Coiled Basketry. New York: Springer.

Dufault, Robert, J. Mary Jackson, and Stephen K. Salvo 1993 Sweetgrass: History, Basketry, and Constraints to Industry Growth. In New Crops. J. Janick and J.E. Simon, eds. pp. 442-45. New York: Simon.

Duncan, James, and Nancy Duncan 2004 Landscapes of Privilege: The Politics of the Aesthetic in an American Suburb. New York: Routledge.

Earley, Lawrence S. 2004 Looking for Longleaf: The Fall and Rise of an American Forest. Chapel Hill, NC: University of North Carolina Press.

Emery, Marla, and Alan Pierce 2006 Interrupting the Telos: Locating Subsistence in Contemporary U.S. forests. Environment and Planning A 37(6):98I-93.

Emery, Marla, Clare Ginger, Siri Newman, and Michael R.B. Giammusso 2002 Special Forest Froducts in Context: Gatherers and Gathering in the Eastern United States. General Technical Report, NE-306. Newtown Square, PA: U.S. Department of Agriculture, Forest Service, Northeastern Research Station.

Fairfax, Sally, Lauren Gwin, Mary Ann King, Leigh Raymond, and Laura A. Watt 2004 
Buying Nature: The Limits of Land Acquisition as a Conservation Strategy, 1780-2004. Boston: MIT Press.

Francis, Robert, Jamie Lorimer, and Mike Raco 2012 Urban Ecosystems as 'Natural' Homes for Biogeographical Boundary Crossings. Transactions of the Institute of British Geographers 37: I83-90.

Gabriel, Nate 2006. Urban Non-Timber Forest Products in Philadelphia. Master's Thesis, Department of Geography, Temple University.

Gobster, Paul 2007 Urban Park Restoration and the "Museumification" of Nature. Nature and Culture 2(2):96-II4.

Gosnell, Hannah, and Jesse Abrams 20II Amenity Migration: Diverse Conceptualizations of Drivers, Socioeconomic Dimensions, and Emerging Challenges. GeoJournal 76(4):303-32.

Grabbatin, Brian, Patrick Hurley, and Angela Halfacre 20II "I Still Have the Old Tradition": The co-production of sweetgrass basketry and coastal development. Geoforum $42(6): 638-49$.

Grimm, Nancy, Stanley Faeth, Nancy Golubiewski, Charles Redman, Jianguo Wu, Xuemei Bai, and John Briggs 2008 Global Change and the Ecology of Cities. Science 319:756-60.

Halfacre, Angela 2012 Delicate Balance: Constructing a Conservation Culture in the South Carolina Lowcountry. Columbia: University of South Carolina Press.

Halfacre, Angela, Patrick Hurley, and Brian Grabbatin 20I0 Sewing Environmental Justice into African-American Sweetgrass Basket-Making in the South Carolina Lowcountry. The Southeastern Geographer 5O(I): I $47-68$.

Hart, Zacchary, Angela Halfacre, and Marianne Burke 2004 Community Participation in Preservation Of Lowcountry South Carolina Sweetgrass (Muhlenbergia filipes [m. A. Curtis] j. Pinson and w. Batson) basketry. Economic Botany 58(2):I6I-7I.
Heynen, Nik 2003 The Scalar Production of Injustice within the Urban Forest. Antipode 35(5):980-98.

Heynen, Nik, Maria Kaika, and Eric Swyngadouw 2006 In The Nature of Cities: Urban Political Ecology and the Politics of Urban Metabolism. New York: Routledge.

Hostetler, Mark, Will Allen, and Collin Meurk 20II Conserving Urban Biodiversity? Creating Green Infrastructure is Only the First Step. Landscape and Urban Planning I00:369-7I.

Hurley, Patrick, and Angela Halfacre 2OII Dodging Alligators, Rattlesnakes, and Backyard Docks: A Political Ecology of Sweetgrass Basket-Making and Conservation in the South Carolina Lowcountry. GeoJournal 76(4):383-99.

Hurley, Patrick, Brian Grabbatin, Angela Halfacre, and Cari Goetcheus 2012 Gathering, Buying, and Growing grass: Urbanization and Social Networking in the Sweetgrass Basket-Making Industry of Lowcountry South Carolina. In African Ethnobotany in the Americas Robert Voeks and John Rashford, eds. pp. 153-74. New York: Springer Publishers.

Hurley, Patrick, with Angela Halfacre, Norm Levine, and Marianne Burke 2008 Finding a "Disappearing" Nontimber Forest Resource: Using Grounded Visualization to Explore Urbanization Impacts on Sweetgrass Basketmaking in Greater Mt. Pleasant, SC. Professional Geographer 60(4): I-23.

Hurley, Patrick, and Peter Walker 2004 Whose Vision? Conspiracy Theory and Land-Use Planning in Nevada County, California. Environment and Planning A 36(9): I529-47.

Hurley, Patrick, and Shakiya Canty In press (Re)Constructing Community Commons and Traditions: Urban Gardening in the Haddington Neighborhood of West Philadelphia. In The Land Speaks, Debbie Lee and Kathy Newfont, eds. London: Oxford University Press. 
Jahnige, Paul 2002 The Hidden Bounty of the Urban Forest. In Nontimber Forest Products in the United States. Eric T. Jones, Rebecca J. McLain, and James Weigand, eds. pp. 96-Ior. Lawrence: University Press of Kansas.

Jorgensen, Anna, and Richard Keenan 2012 Urban wildscapes. Oxford: Routledge.

Knigge, LeDona, and Meghan Cope 2006 Grounded Visualization: Integrating Analysis of Qualitative and Quantitative Data Through Grounded Theory and Visualization. Environment and Planning A 38(II):202 I-37.

Kobori, Hiromi, and Richard B. Primack 2003 Participatory Conservation Approaches for Satoyama, The Traditional Forest and Agricultural Landscape of Japan. Ambio 32(4):307-II.

Kosek, Jake 2006 Understories: The Political Lives of New Mexico's Forests. Durham: Duke University Press.

Lachmund, Jens 20I3 Greening Berlin: The Co-production of Science, Politics, and Urban Nature. Cambridge, MA: MIT University Press.

Lee, Caroline 2009 Conservation as Territorial Ideology. City and Community 8(3):30I-28.

Levitan, Dave 20I3 To Tackle Runoff, Cities Turn to Green Initiatives. Yale Environment 360. http://e360.yale.edu/feature/ to_tackle_runoff_cities_turn_to_green_initiatives/2613/, accessed January27, 2013.

Madsen, Lene Møller, and Hanne Kirstine Adriansen 2004 Understanding the Use of Rural Space: The Need for Multi-Methods. Journal of Rural Studies 20:485-97.

Mason, Robert 20I2 Metropolitan Philadelphia: Sprawl, Shrinkage, and Sustainability. In Nature's Entrepot: Philadelphia's Urban Sphere and its Environmental Thresholds. Brian C. Black and Michael J. Chiarappa, eds. pp. I87-206 Pittsburgh: University of Pittsburgh Press.

McGovern, Stephen J. 2006 Philadelphia's Neighborhood Transformation Initiative: A Case Study of Mayoral Leadership, Bold
Planning, and Conflict. Housing Policy Debate I7(3):529-70.

McLain, Rebecca, Patrick Hurley, Marla Emery, and Melissa Poe 2013 Rethinking Urban Green Space Planning through the Lens of NTFPs and Foraging in U.S. Cities. Local Environments.

Neumann, Roderick 1998 Imposing Wilderness: Struggles over Livelihood and Nature Preservation in Africa. Berkeley: University of California Press.

Natural Lands Trust 2012 Natlands.org. www. natlands.org/, accessed August I4, 2012.

Odum, Howard T. 2007 Environment, Power And Society for The Twenty-First Century: The Hierarchy of Energy. New York: Columbia University Press.

Peluso, Nancy I992 Rich Forests, Poor People. Berkeley: University of California Press.

Penn Praxis 20ir Green2ors: An Action Plan for the First 500 Acres. Penn Praxis. http:// issuu.com/pennpraxis/docs/green20I5_full/, accessed December 3I, 2 OI2.

Pennsylvania Department of Conservation and Natural Resources 20I2 Pennsylvania State Parks. www.dcnr.state.pa.us/stateparks/ index.aspx, accessed August I4, 2012.

Pennsylvania Game Commission 2009 Pennsylvania's Deer Chronicle. Bureau of Wildlife Management 2(I).

Pennsylvania Game Commission 20II Pennsylvania Deer Hunter Survey. Bureau of Wildlife Management.

Pincetl, Stephanie 20I0 From the Sanitary City to The Sustainable City: Challenges to Institutionalising Biogenic (Nature's Services) Infrastructure. Local Environments I5 (I): $43-58$.

Peterson, Leif, E. Moll, R. Collins, and Marc Hockings 2012 Development of a Compendium of Local, Wild-Harvested Species Used in the Informal Economy Trade, Cape Town, South Africa. Ecology \& Society I7 (2): I-26.

Poe, Melissa, Rebecca McLain, Marla Emery, and Patrick Hurley 20I3 Urban Forest 
Justice: NTFP Gathering and the Rights to Wild Foods, Medicines, and Materials in Seattle. Human Ecology 41:409-22.

Proceedings 1988 Proceedings of the Sweetgrass Basket Conference. Charleston, SC: University of South Carolina.

Robbins, Paul 2012 Political Ecology: A Critical Introduction, 2nd Edition. Malden: Blackwell Publishing.

Robbins, Paul 2006 The politics of Barstool Biology: Environmental Knowledge and Power in Greater Northern Yellowstone. Geoforum 37(2): I85-9.

Robbins, Paul, Marla Emery, and Jennifer Rice 2008 Gathering in Thoreau's Backyard: Nontimber Forest Product Harvesting as a Practice. Area 40(2):265-77.

Rosengarten, Dale I987 Row Upon Row, Sea Grass Baskets of the South Carolina Lowcountry. McKissick Museum: University of South Carolina.

Rosengarten, Dale 1994 "Sweetgrass is Gold": Natural Resources, Conservation Policy, and African American Basketry. In The Crucible of Carolina: Essays in the Development of Gullah Language and Culture. Michael Montgomery, ed. pp. I52-63. Athens, GA: University of Georgia Press.

Rybczynski, Witold 2007 Last Harvest: How a Cornfield Became New Daleville. New York: Scribner.

Schroeder, Richard I999 Shady Practices: Agroforestry and Gender Politics in The
Gambia. Berkeley: University of California Press.

Sivaramakrishnan, Kalyanakrishnan 2000 Crafting the Public Sphere in the Forests of West Bengal: Democracy, Development, and Political Action. American Ethnologist 27:43I-6I.

U.S. Census 2000 Census Fact Finder. www.census.gov/, accessed December i6. 2007.

U.S. Census 20I0 American Fact Finder (2010 Census). www.census.gov/, accessed August 5, 2013 .

United Nations Population Fund 2007 State of the World Population 2007: Unleashing the Potential of Urban Growth. Document \# 31367I. New York: UNFPA.

United States Department of Agriculture 2007. Pennsylvania's Forest 2004. Resource Bulletin NRS-20. U.S. Forest Service Northern Research Station.

Walker, Peter, Sarah Marvin, and Louise Fortmann 2003 Landscape changes in Nevada County reflect social and ecological transitions. California Agriculture 57(4):II5-2 I.

Wehi, Priscilla M., and William L. Wehi 2009 Traditional Plant Harvesting in Contemporary Fragmented and Urban Landscapes. Conservation Biology 24(2):594-604.

Wild Foodies of Philadelphia 20I2 Meet Up Homepage. www.meetup.com/WildFoodies-of-Philly/, accessed August I4, 2012. 
NEW DIRECTIONS IN SUSTAINABILITY

AND SOCIETY

SERIES EDITORS:

CHRISTOPHER BOONE

Arizona State University'

NORMAN YOFFEE

University of Michigan

EDITORIAL BOARD:

KATRINA BROWN

University of Exeter

STEWARD PICKETT

Cary Institute

STEPHANIE PINCETL

\section{UCLA}

VERNON SCARBOROUGH

University of Cincinnati

\section{KAREN SETO}

Yale University

DAN SHILLING

Amerind Muscum and Research Center

\section{SUSTAINABILITY IN THE}

\section{GLOBAL CITY}

Myth and Practice

Edited by

\section{CINDY ISENHOUR}

WILLIAM SOLECKI

Hunter College

CHRISTINE SZUTER

Amerind Museum and Research Center

KAZUHIKO TAKEUCHI

University of Tokyo

BILLIE LEE TURNER

Arizona Statc University

SANDER VAN DER LEEUW

Arizona State University

RICHARD WILK

Indiana University

Published in conjunction with the School of Sustainability at Arizona State University and The Amerind Museum and Research Center in Dragoon, Arizona, New Directions in Sustainability and Society features a program of books that focus on designing a resilient and sustainable future through a rich understanding of past and present social and ecological dynamics. Collectively, they demonstrate that sustainability research requires engagement with a range of fields spanning the social and natural sciences, humanities, and applied sciences. Books in the series show that a successful transition to a sustainable future will depend on the ability to apply lessons from past societies and link local action to global processes.

For more information about the series, please visit http://newdirections .asu.edu/. 


\section{CAMBRIDGE UNIVERSITY PRESS}

32 Avenue of the Americas, New York, NY 10013-2473, USA

Cambridge University Press is part of the University of Cambridge.

It furthers the University's mission by disseminating knowledge in the pursuit of education, learning, and research at the highest international levels of excelience.

www.canoridge.org

Information on this title: iwww.canbridge.org/9781107076280

(c) Cambridge University Press 2015

This publication is in copyright. Subject to statutory exception and to the provisions of relevant collective licensing agrements, no reproduction of any part may take place without the written permission of Cambridge University Press.

First published 2015

A catalog record for this publication is arailable from the British Library.

\section{Library of Congress Cotaloging in Publication Data}

Sustainability in the global city : nyth and practice / edited by Cindy Isenlour, University of Maine; Gary Mcl Donogh, Bryn Mawr College; Melissa Checker, Queens College, CUNY.

pages $\mathrm{cm}$. - (New directions in sustainability and society series)

ISBN 978-1-107-07628-0 (Hardback)

1. Sustainable urban development. 2. Urban anthropology. 3. Urban ecology (Sociology) 4. Urbanization-Social aspects. I. Isenhour, Cindy, author, editor of compilation. II. Mcl Jonogh, Gary W.. author, editor of compilation. III. Checker, Melissa, author, editor of compilation.

HT 241.S86 2015

$307.76-d c 232014021015$

ISBN 978-I-107-07628-0 Hardback

Cambridge University Press has no responsibility for the persistence or accuracy of unLs for external or third-party Internet websites referred to in this publication and does not guarantee that any content on such websites is, or will remain, accurate or appropriate. 